\title{
“IT CAN CRY, IT CAN SPEAK, IT CAN PEE": MODALITY VALUES AND PLAYING AFFORDANCES IN CONTEMPORARY BABY DOLLS' DISCOURSE
}

\author{
Danielle Barbosa Lins de Almeida ${ }^{1^{*}}$ \\ ${ }^{1}$ Universidade Federal da Paraíba, João Pessoa, Paraíba, Brasil
}

\begin{abstract}
Baby dolls have been in the toy market for more than a hundred years, since French firm Jumeau entered the toy industry in the nineteenth century and started producing "bébés", considered the greatest phenomena of the toy market (Fleming, 1996). The aim of this analysis is to shed some light on the multimodal properties provided by the aural, verbal and visual texts of the packages of Brazilian baby dolls through a careful look at their textual and contextual meanings, anchored on Kress \& Van Leeuwen's (2006) subsystem of modality (reality value), within the interpersonal visual metafunction. The analyses of the baby dolls' packages point to roles suggested to young girls from a very early age, varying from parenting roles they are asked to fullfill later in life as future mothers to medical abilities they are encouraged to master in order to care and nurture for their "children".

Keywords: Baby dolls; Multimodality; Modality values; Children; Play.
\end{abstract}

\footnotetext{
"Holds a postdoctoral degree from the Universidad de Buenos Aires (UBA), where she worked as a visiting scholar in 2013. Her PhD research at Federal University of Santa Catarina included co-tutoring studies at the University of New South Wales in Sydney, Australia. She is currently an Associate Professor at the Federal University of Paraíba, Brazil. Her e-mail address is danielle.almeida@gmail.com. ORCID: https://orcid. org/0000-0003-1472-6083.
} 


\section{Introduction: Baby Dolls}

The history of baby dolls dates back to the late nineteenth century, when the French toy firm Jumeau took the leadership by introducing the first Bébé Jumeau, whose physical features were quite distinguishable from those ubiquitous now in the twnty-first century. At that time, baby dolls were mostly cherished by adult collectors, as bébé dolls had a strong relationship with French Haute Couture (Peers, 2004). Besides, bébés were often dressed in adult female clothes although Peers (ibid.) does report that "the whole bébé phenomenon evaporated in Haute Couture [...] under pressure from commercialisation and mass production" (Peers, 2004, p. 70).

According to her, the origins of the baby doll are core to provide a better understanding of the history of the fashion doll boom, as the "the French bébé as a genre proves a particularly rich prehistory to the issues of branding and marketing" (Peers, 2004, p. 71) nowadays experienced by fashion dolls. Be that as it may, the truth is that throughout the nineteenth century the baby doll Bébé Jumeau was virtually everywhere: in pamphlets, engravings, lithographs, children's stories as well as in adult's print media (Peers, 2004).

The most important public service of such doll, as Peers (2014) contends, was possibly the regulation of womanhood, as young girls' negotiation to be given a bébé as a reward for their "appropriate feminine behaviour", not only encouraged them to comply with certain pre-established social roles but also "permitted a pre-industrial revolution division of gender roles within the family, where female labour (...) made a positive and necessary contribution to the overall economic viability of the family unit" (Peers, 2004, p. 78).

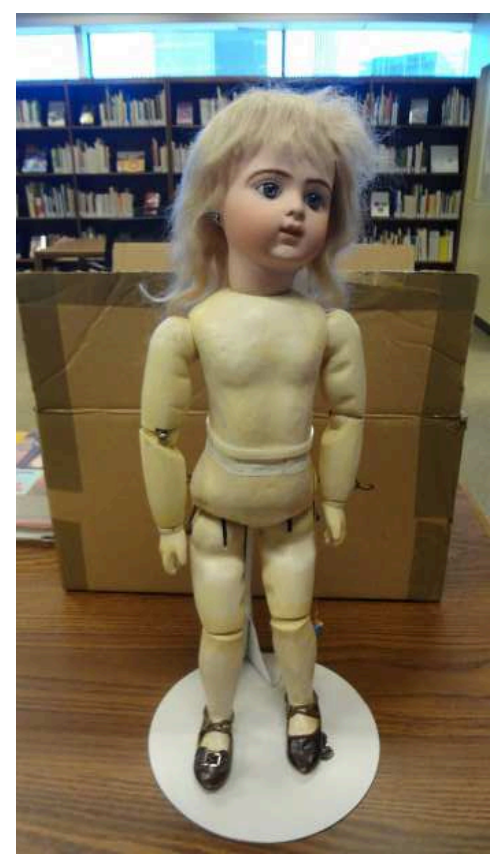

Figure 1: Kiss Bru Doll (1885)

Courtesy of The Strong, Rochester, New York 
Indeed, in the book Out of the Garden: Toys and Children's Culture in the Age of TV Marketing, Stephen Kline (1993) points out that whenever a girl scolds her doll for not finishing dinner, she is actually playing at being a mother, which sustains toys' function as props for the (early) social-dramatic enactment of specific roles they will take up later in a specific social universe.

From a visual aspect, at first, the bebés'ensembles were usually designed in pastel shades, which included pinks, blues, aquamarine and creams. Later, with the introduction of the small and artisanal Bru company in the baby doll market, the dresses started to be cut in "darker, more intense shades of fabrics, such as royal blues, ruby reds and deep wine reds", as the Bébé Brus were always "elegantly dressed and in the latest fashion" (Peers, 2004, p. 79-81). By then, four were the main Paris-based firms producing bébé-baby dolls: Jumeau, Bru, Steiner and Gaultier, all of which, with the exception of Jumeau, operated on a smaller, artisanal scale.
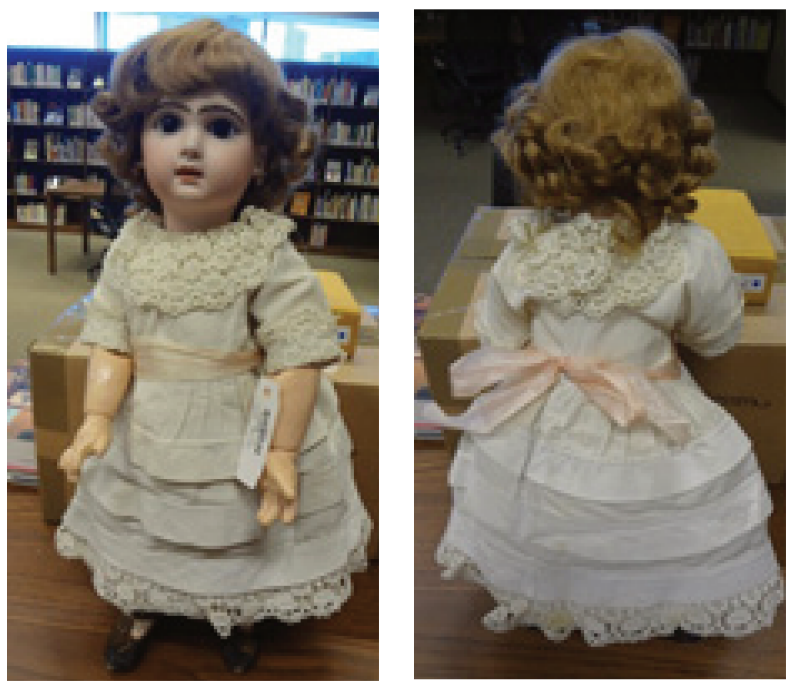

Figure 2: Kiss Tete Jumeau (1880-1890) Courtesy of The Strong, Rochester, New York
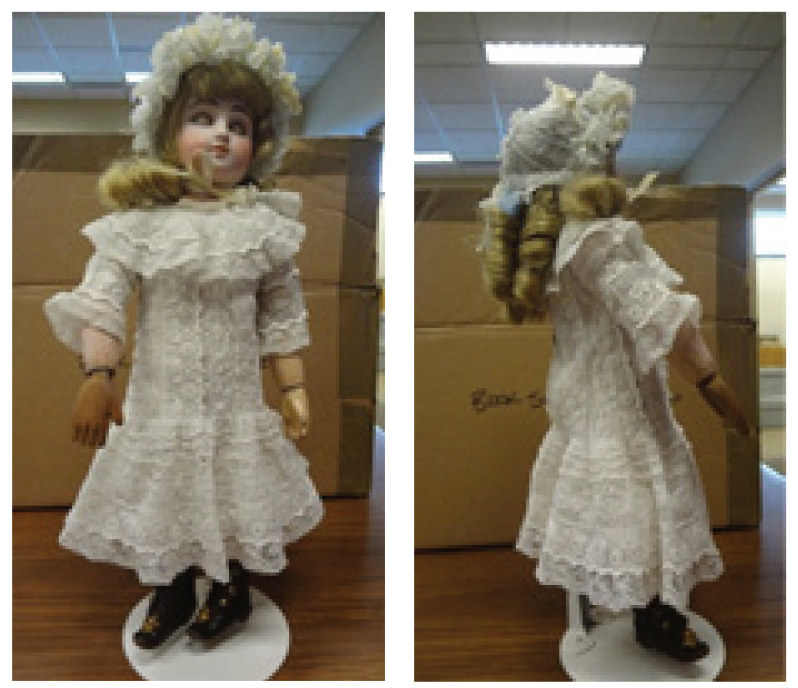

Figure 3: Cecilie Therese (1886)

Toys like baby dolls are usually assigned specific functions through their design and advertising, which gives young girls no option but to go on with the suggested mothering playing script. Following Kline's (ibid) train of thought, whenever a talking baby doll says hug me mummy or feed me and the little girl in the advertisement or package follows the commands, she is being compliant to what society expects her to do. 

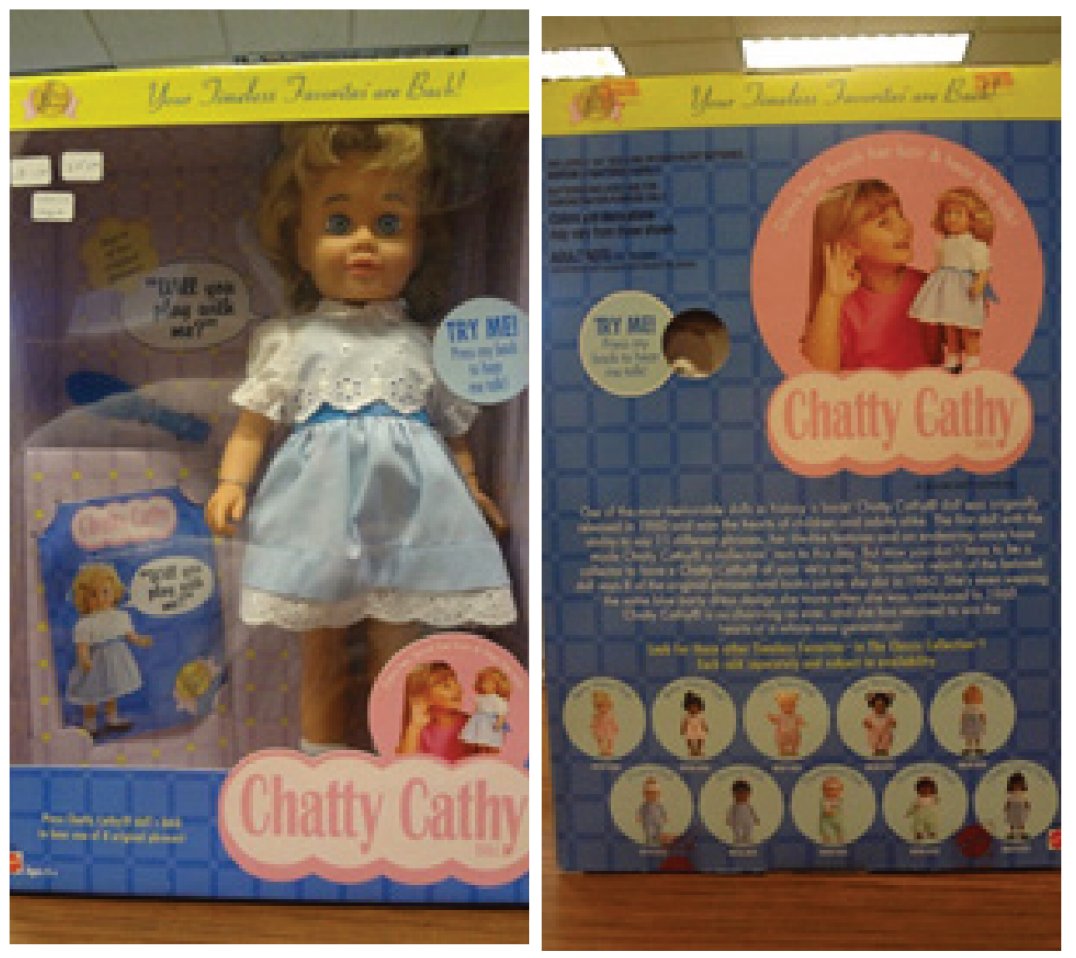

Figure 4: Chatty Cathy Doll (1885)

Courtesy of The Strong, Rochester, New York

As the representation of a child - an infant - the baby doll encapsulates concepts such as purity and cuddliness as well as dependence, companionship and loyalty. Attested in the box of the iconic Bébé Jumeau as a letter to her potential owner and quoted by doll historian Melger (1997, p. 40, as cited in Peers, 2004), the nineteenth marketed language of baby doll Jumeau's package reads:

I have promised myself many happy days in your company. I will be obedient and sociable and above all so undemanding of you that you shall quickly find me dear to you, because I do not want to be your loving, unbreakable doll, but also a friend who knows how to console you when your heart is heavy from difficulties. In addition to obedience, I have many other qualities which set me apart from other babies. Firstly I am discreet and most of all deaf and dumb since my birth, so that you can count on me never repeating your words to anyone or gossiping about anything you may have done. My large blue eyes shine so beautifully, will never betray my emotions. [punctuation sic] (p. 69)

Fast forward to twenty-first century baby dolls' packages, the present study aims at verifying the multimodal properties of their advertising language, which includes the visual and verbal texts as well as the aural, tactile and olfactory aspects of these dolls. The analyses will attempt to shed some light on both textual and contextual meanings, as baby dolls are often relating little girls to parenting roles they are asked to fullfill later in life.

In the next section I will discuss some of the key aspects of the system of modality within the interpersonal metafunction of Kress \& van Leeuwen's (2006) Visual Grammar and how it relates to the modality values embedded in contemporary baby dolls. 


\section{Modality Values}

As objects appealing to both children and adult's markets, baby dolls, since their industrial expansion in late nineteenth century, have been following two tendencies pinpointed by Fleming (1996), named tactile and harder representationality, which account for features that pertain to our present days. The first is related to the flexibility and sense of cuddliness of some dolls initiated with the Teddy Bear production in 1903, whereas the second is associated to the high degree of realism of baby-like dolls which started with the Jumeau'bébés' and culminated in the reborn baby doll phenomenon observed in contemporary times. The latter are highly naturalistic dolls made from vinyl or silicon,

with the skin painted in many translucent layers to achieve a mottled baby skin tone, including the appearance of veins and capillaries, birthmarks and scratches. The dolls look and feel like real babies, with bodies weighted to match the heft of a live infant. They have mohair (or real hair) rooted in their heads in individual strands, and a magnet in the mouth to hold a magnet pacifier. Some artisans make dolls with a heartbeat and a raising and falling chest that simulates breathing. (William, 2011, as mentioned in Knafo, 2017)

The degree of compatibility between what we see represented and what the object is in real life is referred to by Kress and van Leeuwen (2006) as modality or reality value, which accounts for the level of proximity between a given representation and what we see with the naked eye.

Indeed, naturalistic modality is defined on the basis of congruence: the greater the correspondence with the real object, the higher the naturalism of an image. One of the ways to grade such congruence is through colour, as it exerts a great influence on naturalistic modality.

Another variable that affects the level of naturalistic modality in a representation refers to its contextualization, its background. Generally speaking, the presence of background in an image increases its modality from a naturalistic perspective whereas the absence of background lowers it.

In the case of toys like the baby dolls hereby analysed, they deserve to be interpreted according to "various dimensions of tactility, maybe including weight: the more an object that represents some other object feels and handles like that other object, the higher its modality" (Machin and van Leeuwen, 2009, p. 58) .

There are four main categories within the system of modality: naturalistic (or real), sensory (or fantastic), scientific and abstract modality, as can be visualized in Figure 5 that follows. 


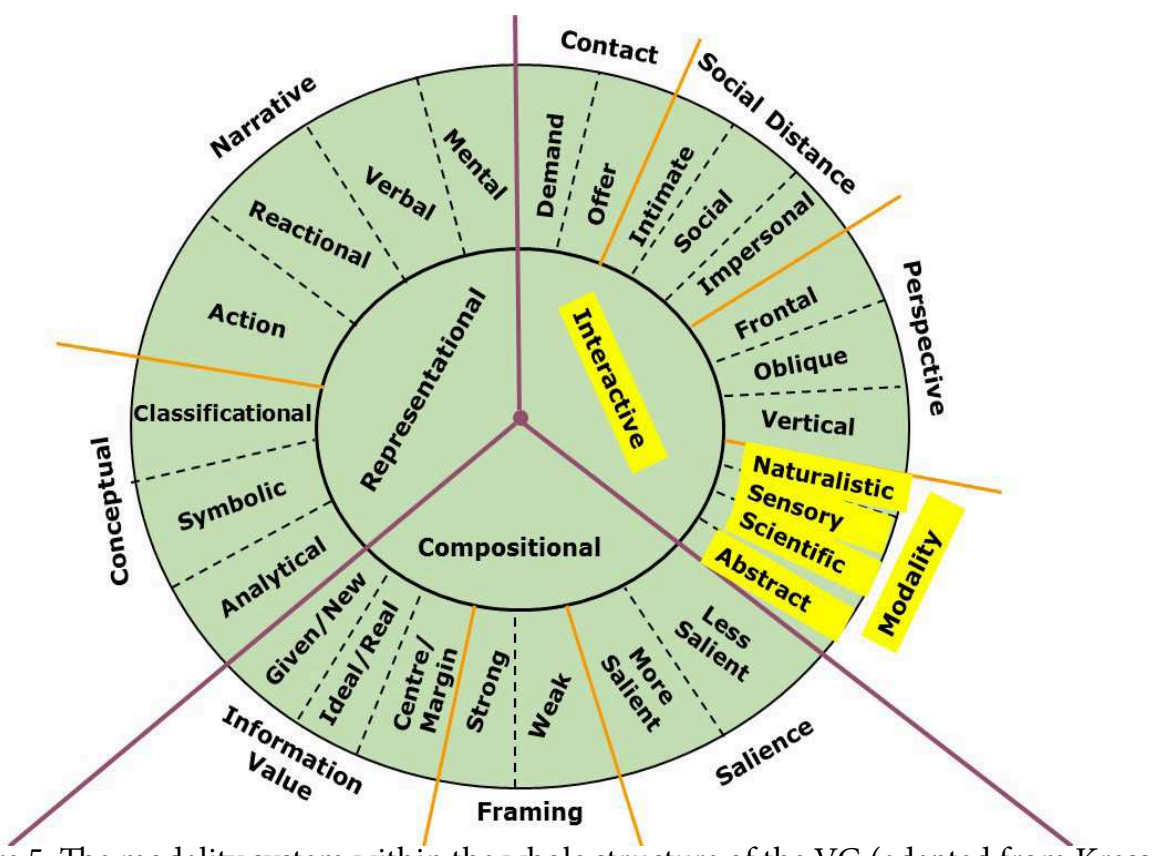

Figure 5: The modality system within the whole structure of the VG (adapted from Kress \& van Leeuwen, 2006)

Just as important as understanding that the concept of modality relies on a gradation system based on variables that help defining how naturalistic a representation may be, is the understanding that a represented image should also be looked at from the perspective of the context where it is inserted.

That requires sensitivity on the part of the analyst, who should consider, as Ravelli (2013) contends, taking

coding orientation into account: how 'real' something is depends entirely on from whose point of view this is presented [...] It might be high modality from a scientific coding orientation, where you want to emphasise the credibility and factuality of the information. Or it might be high modality from a naturalistic coding orientation [...] or it might even be high modality from a fantasy coding orientation. (p. 236-237)

Besides the naturalistic values of a given representation are its sensorial values - named sensory (or fantastic) modality by Kress and van Leeuwen (2006). They are directly associated to the way a given representation affects its viewer: the higher the impact, the higher its sensorial level of modality. Images with a high level of sensory modality are depicted so as to evoke subjective feelings from the viewer (Machin and van Leeuwen, 2009).

While applying these concepts to children's toys, like toy guns, in their multimodal analysis of contemporary war toys, Machin and van Leeuwen (2009) have concluded that although their visual modality may be regarded as very high - as some toy guns might look like real replicas of actual guns - on the tactile and aural level, these toys' modality level is actually very low, as they may be surprisingly light in terms of weight, therefore being far from the real thing and somehow amusing in terms of their sound effects, in that they "sacrifice 
verisimilitude for pleasure and sensation [through] bright colours, flickering lights, quasi-musical sound" (Machin and van Leeuwen, 2009, p. 58).

Apart from the naturalistic and sensorial features of a representation are the images characterized by a high scientific level of modality, which leave out background, thus simplifying detail. In such representations, colour and depth are regarded as superfluous (Kress \& van Leeuwen, 2006).

Last but not least, the coding orientation that modulates the abstract modality is based neither on verisimilitude nor on impact, "but on how things are in general and regularly, or according to some deeper, hidden truth" (Jewitt \& Oyama, 2001, p. 151).

Table 1 depicts a brief view of the system of modality within the interactive metafunction by summarising what has hitherto been described:

Table 1: Realizations and Meanings of the Visual System of Modality (adapted from Kress \& van Leeuwen, 1996, p.121-154 and taken from Almeida, 2006)

\begin{tabular}{|c|c|c|}
\hline Mealization & Meaning \\
\hline Modality & $\begin{array}{c}\text { naturalistic: high degree of } \\
\text { realism }\end{array}$ & $\begin{array}{c}\text { naturalistic: sense of 'real' } \\
\text { sensory: 'more-than-real' sense, } \\
\text { evokes subjective feelings } \\
\text { ism } \\
\text { scientific: } \text { effectiveness of visual } \\
\text { representation as 'blueprint' } \\
\text { scientific/technological: low } \\
\text { degree of realism, abstracts } \\
\text { from detail }\end{array}$ \\
$\begin{array}{c}\text { abstract: low degree of real- } \\
\text { ism }\end{array}$ & \\
\hline
\end{tabular}

Next, I will approach the concept of playing affordances in order to check out how the values elicited by contemporary baby dolls are related to the roles society expects them to fulfill.

\section{Playing Affordances}

Regarded as transitional objects by psychologists like Winnicott (1971), toys have also been assigned the role of miniature versions of the objects children will handle as adults (Machin and van Leeuwen, 2009). Therefore, the meanings they carry are believed to anticipate real life practices they will deal with in the future.

The question that remains is whether baby dolls foster creativity in playing or if, through their pre-established props, they end up limiting children's imaginative potential in relation to playing. In other words, does baby dolls' realism enhance the fixing up of little girls' identity as future mothers?

The scripts - or playing possibilities - offered by toys' representations are described by Brougère (2014) as affordances, linked to the structures for the play that are proposed by its design, shape, colours, etc. In this respect, 
Peers (2004) states that the more lifelike a baby doll is, the more prescriptive it becomes. She adds that

[Later] in the $20^{\text {th }}$ century, plastic baby dolls were modelled as genitally complete, and sold with umbilical binding and identity tag, as if the child who received it had recently given birth to it, in a further move to realism in representing babies. (p. 105)
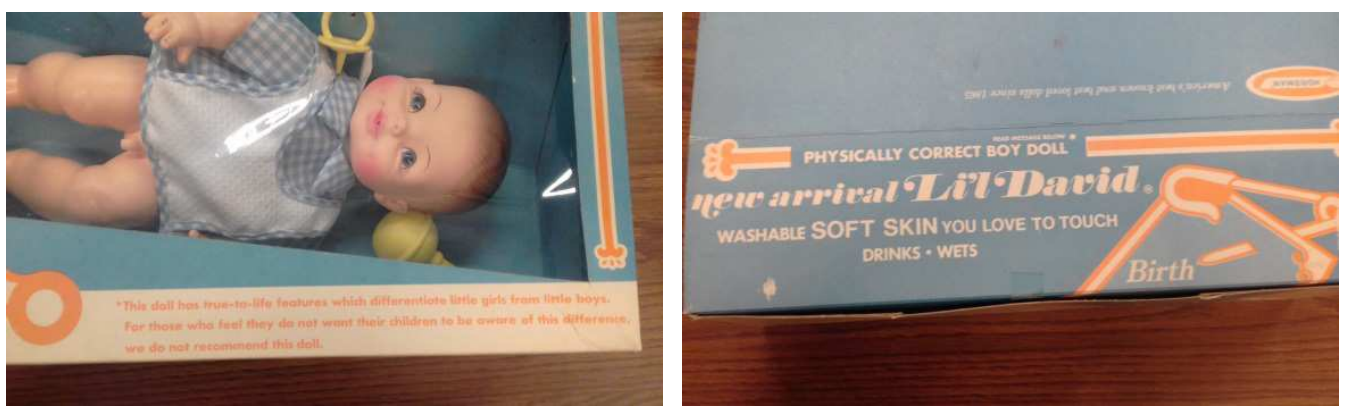

Figure 6: Li'l David, by Horsman (1977)

Courtesy of The Strong, Rochester, New York

She highlights the lack of academic research about baby dolls' meaningmaking potentials but does mention Inness' (1999) concern while quoting her statement about what she calls the "modern proliferation of baby dolls":

I was surrounded by baby dolls that all conveyed the same message that having a baby is the greatest experience of a woman's life, and every girl should want a baby more than anything else. These dolls did not teach about the importance of travel and adventure; they taught about the importance of maternity and domesticity. They also conveyed the completely unrealistic message that babies are all a woman (or a girl) needs for complete bliss. Lessons like this can lead many girls to have babies while still teenagers, thinking that children are enough to fill someone's life with joy. (Sherrie, A. Inness, 1999, as mentioned in Peers, 2004, p. 80)

By bringing Inness' (ibid.) perception to the forefront of discussion, Peers (ibid) believes that just like Barbie, who has historically been a source of critical and cultural analysis, baby dolls should also be de-constructed insofar as their general assumption of "naturalness, beneficence and neutrality" are concerned, for they, too, carry important messages to be discussed.

One of these messages is related to their lovability, ${ }^{1}$ as the word "love" has become a rather recurrent term in these dolls' packages, advertising catalogues and other promotional media venues such as websites and advertisements, although the connotations it carries may assume any of the following four meanings suggested by Varney (2002):

(1) representational love, aimed at picturing toys as true material proofs of love; 
(2) substitutional love, aimed at minimising working parents' feeling of guilt for not spending enough time with their children as a consequence of the pressures of modern life;

(3) obligatory and (4) romantic love, regarded as strongly gendered, as toys contributing to a concept of love as obligation train girls for a motherhood role that ensures they will be emotionally as well as physically equipped (extracted and adapted from Varney, 2002, p. 03) [my italics].

The selling of what Varney (2002) has described as love in toytown has made toys to be structured around love themes which underpin the marketing interests of today's toy makers. Through a process regarded as "privatisation of playing" (Varney, 1999), the appeal of loving toys has modified the concept of socialization in toy-playing by promoting the idea that the companionship of a child no longer needs to be another child but a toy. Toy manufacturers have of course benefited from this trend and made good use of it, by explicitly offering Best Friend Teddy Bears or My Puppy Loves Me lines to substitute for real human friends or companions.

The turning of toys into imaginary companions has been claimed not only to strengthen children's attachment bonds with these toys but also to "signify the emotional experiences of imaginary friends and family relations" (Kline, 1993, p. 259). One of the ways this can be connoted is through the child's tactile relationship with the toy, a bond of love which is expressed through "kissing, hugging, and constant companionship" (ibid.).

In a compendious survey carried out by Kline (1993), aspects of doll-playing such as children's potential to negotiate the meanings offered by dolls' media marketing were investigated, mainly triggered by the question "Who or what is the child identifying with when playing with media-marketed toys?" (mentioned in Fleming, 1996, p. 29-30).

While reporting his results, Kline (ibid.) explained that his respondents tended to fall into two categories. The first one composed of the extreme pessimists, who contended that identification with media-marketed toys such as GI Joe and Barbie generally occurs on the basis of

(...) simplistic, male-dominated perspectives, reliant on violence to solve problems or glamour-doll objectification, primping and posing for the invisible watcher who is always assumed to be there - whether Daddy, boyfriend or envious other girls. (...) (Kline, mentioned in Fleming, p. 30)

In other words, pessimists tended to view the opportunities for meaningmaking negotiation as "too tightly scripted in advance to allow any genuine imaginative activity" (ibid.), as according to them, "all that the child can do is copy the formulae" (ibid.).

On the second category were the optimist ones, who believed on children's "inherent capacity to transcend such pre-imposed limitations to use given identifications and opportunities as starting points, as resources to be imaginatively reworked" (ibid.). 
Be that as it may, whether children are either constrained by toys' offered "narrative universe" (Kline, 1993) or whether they are able to transcend it, the active role of the child-imaginer is essential to challenge the suggested identities so that s/he can create his/her own fictive scripts, wherein toys like baby dolls can acquire new dimensions as effective media for children's socialization and expression of reality.

\section{Contemporary Brazilian Baby dolls}

To study baby dolls' representations as visual communication enables us to check how the child fits into society by means of a material culture.

In line with Peers' view (2004), Brougère (2014) also believes that research in the direction of toys' meaning-making potential as an object that "talks" directly to the child has been quite scant, as attested in 20 years of the conference of the ITRA - the International Toy Research Association - whose emphasis has been frequently given to toys' educational use, play and effects but rarely to their multimodal analyses as material properties.

According to him, (ibid), toys can be regarded as visual communication inasmuch as they communicate an image to the child, the image of the world where the child can play. In one of their studies devoted to toys' multimodal aspects, van Leeuwen \& Caldas- Coulthard's (2000) investigate the iconography of pram rattles as baby toys, by pursuing a deeper interpretation of their given motifs - or "visual pointers" (ibid.) - as clues to the meanings that these toys' symbology features.

We already know that baby dolls' representations frequently imply motherhood duties, as the realism of a life-like infant usually conduces little girls to develop nurturing, homemaking and medical abilities. Kline (1993) points out that we are not exposed to seeing a baby doll in advertising as "a warrior, or a dump truck used to take baby for a walk" (p. 251) although this may easily happen at the child's private, domestic sphere. His main contention is that certain toys are more prescriptive than others, and that baby dolls may fall into this category. In Kline's own words,

symbolic design is the process marketers use to narrow the representational fields of the toy (product design, advertising, programming) to depict a specific role portrayal in a specific social universe. (p. 251)

This may be related to what Brougère (2014) describes as toys' affordances for playing. He gives the example of the Barbie doll, who, though revolutionary in terms of historical meanings, remains conservative at the level of her playing affordances:

[...] "thus we find styling hair, dressing, as well as the bath - in a pool as opposed to the same function attached to the baby doll" (p.247). 
Nevertheless, in their aforementioned study on the potential meanings elicited by toy guns and their multimodal properties, Machin and van Leeuwen (2009) have stated that the interrelation between war toys' representational function and their playing affordances may not be so clearcut, as children playing with them seem to know how to distinguish the "good guys" from the "bad" ones, to recognize what guns are for and therefore may not necessarily desire to become soldiers themselves (p. 59).

Having made these points clear, I now turn to the analysis of the multimodal properties verified in the packages of Brazilian baby dolls, with a view to providing a discussion of their embedded meanings.

During an ethnographic visit to a toy store in northeastern Brazil on Brazilian Children's Day on $12^{\text {th }}$ October 2016, a total of 10 (ten) baby doll packages were photographed: Bebê Banhinho, Nenezão, Minha Dodoizinha Gessinho, Cheirinho de Bebê, Bebê Fraldinha, Baby Alive, Analu Sorinho, Betsy Doll, Nina and Nino's $B a b y$, among which 5 (five) will be used for the purpose of this study: Coleção Nino's Baby, Minha Dodoizinha Gessinho, Nina, Betsy Doll and Analu Sorinho, for these specific representations seem to better illustrate my theoretical assumptions.

These dolls will be analysed in relation to their multimodal aspects, which includes their modality (or reality) values, i.e., the degree of realism fostered by their representations. That involves the visual and verbal texts of the packages as well as the aural, tactile and olfactory elements of the dolls' representations.

The findings will be placed in relation to their contextual clues, among which are the roles that baby dolls seem to suggest to young girls. Which roles are these girls expected to assume and how do they relate to women's position in contemporary society? Have these roles changed over the past years? How is this being reflected in toys like baby dolls' representations?

In terms of reality values, it is true to say that the appeal of contemporary toys has been constructed to the extent of surpassing their functionality as the market has been investing large amounts of money in making visual and sound effects tantalise every possible sense of the consumer, probably as a way to resort to what Varney (2002) has described as the obligatory and/or romantic kind of love.

By exerting a sensory attraction on the child, the toy ends up "hypnotizing" him/her and effectively transposing him/her from his/her immediate reality (Fleming, 1996). Some of these toys are designed to scent like flowers, fruits or other flavours, while lighting and sound effects are maximised across the full spectrum of toys, a phenomenon that has been described by Varney (1999) as the "technocracy of sensuality" (p. 20).

That appears to be related to Kress and van Leeuwen's (2006) sensory - or fantasy - coding orientation for modality, whose gradation goes from high to low, depending on how subjectively a representation affects its viewer $(+/$ - sensorial) and how distant or near that represented object is from reality (+/-naturalistic).

Assuming that most baby dolls analysed have been designed to smell, weigh and sound like real babies, we can say that from a tactile, olfactory and aural point of view, the naturalistic degree of their modality is generally targeted at 
being maximised, although from a visual perspective, when compared to the new reborn line of baby dolls - which have not been the object of this analysis - the modality level of mainstream babies found in toy stores can be regarded as low.

Indeed, from a multimodal perspective, the multimodal resources used in Brazilian baby dolls like Coleção Nino’s ${ }^{2}$ (Figure 7) seem to embody what Varney (1999) has named technocracy of sensuality when it is stated, right in the package, that not only does the baby doll inside the box weigh like a real baby, but it also sounds and smells like a real one: ("Com cheirinho de bebê e peso de um bebê de verdade" $)$. In other words, these dolls are produced to appeal to every possible sense.

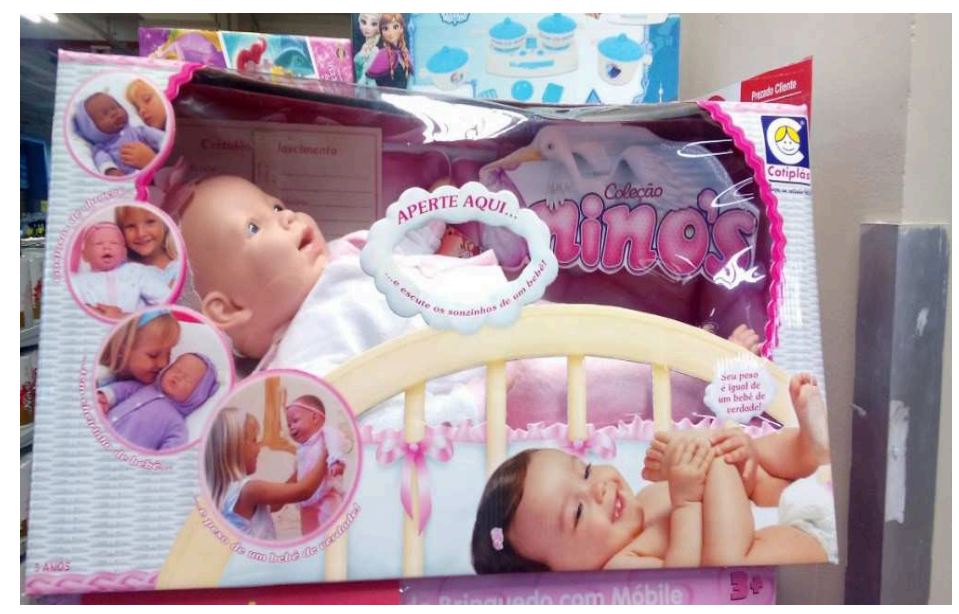

Figure 7: Multimodal features of contemporary baby dolls ${ }^{4}$ [Photo:author]

The baby doll of Coleção Nino's comes in a package emulating a cradle with a cardboard stork placed inside together with a birth certificate, which the childmother is expected to fill out while playing with the doll. The package is coloured in shades of pink, beige and mauve, commonly associated to babyhood. Around the baby doll, in the outside part of the package, realistically depicted as photographs, is a set of four images at the left-hand side, portraying a very young girl caressing and caring for her little baby. At the bottom right-hand side of the box, we can visualize the photograph of a cute real baby, which increases the modality of the package from its naturalistic perspective. The verbal text adds to that by informing the consumer that the weight of the baby doll is just like the one of a real infant ("Seu peso é igual de um bebê de verdade"). The baby doll weighs around 2,4 kilograms and comes in two versions: with the eyes open and with the eyes closed, sleeping.

Also, by pressing the middle part of the package, the child/consumer is invited to hear sounds that emulate real baby ones ("Aperte aqui e escute os sonzinhos de um bebê" $^{\text {"5) }}$ : the baby doll babbles, giggles and cries, which ends up increasing the toy's level of details as far as its naturalistic modality is concerned.

The structure "de verdade" ("like a real one") gets repeated several times in the package of Coleção Nino's as a way to remind the viewer that the baby doll is extremely realistic: it makes sounds, weighs and smells like an actual baby. 
The same structure "de verdade" appears in the package of baby doll Minha Dodoizinha Gessinho ${ }^{6}$ (Figure 8) ${ }^{7}$, which features right at its upper part that the doll's tears are for real - "Lágrimas de verdade" - as the child/consumer is guided through a sort of reading path (Kress \& van Leeuwen, 2006) to go through six realistically depicted photographs of a little girl aged around 3-5 years old, pictured in great salience in the package, establishing a sort of "dialogue" with the child/consumer. She exemplifies - both verbally and visually - tasks which the child-mother is supposed to carry out, taking care of the baby, checking the doll's temperature, applying injections, taking off and putting the plaster, etc.

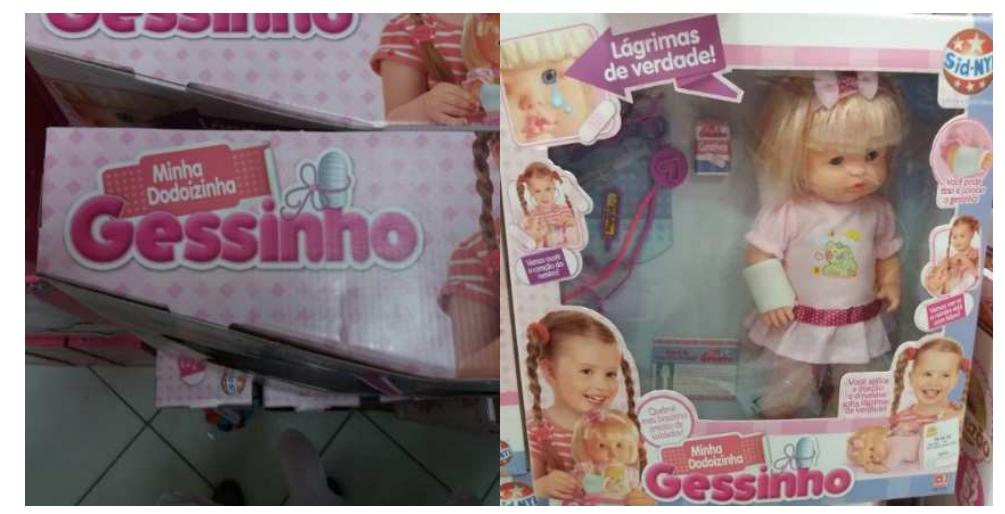

Figure 8: Multimodal features in the package of Brazilian baby doll Minha Dodoizinha Gessinho $^{8}$ [Photo:author]

Inside the box, besides the baby doll, there is a set of items like a plastic stethoscope, a plastic pair of scissors, a thermometer, a syringe and a package of band-aid (sticking plaster), all of which aimed at making the child familiar with first-aid vocabulary.

Instructions on how the child should carry on such medical duties are given both at the verbal and the visual level, as the realistic nature of the activities described: the baby cries out real tears when you apply the injection (Você aplica a injeção e o neném solta lágrimas de verdade"), you may take off and put on her little plaster ("Você pode tirar e colocar o gessinhog"), her heart beats like a real one ("Vamos ouvir o coração do neném?1") and she needs real care because

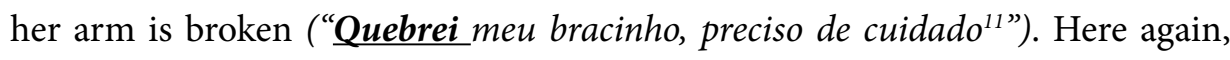
the verisimilitude of the baby gets emphasized by means of verbal and visual resources highlighting the high naturalistic modality with which the doll has been designed, due to its attempted congruence with reality.

Moreover, the text of Brazilian baby doll Minha Dodoizinha Gessinho is constructed in order to create a sense of solidarity with the child, in that interpersonal closeness is instantiated by means of direct interaction through the use of questions that invite him/her to carry out nurturing responsibilities, such as "Let's check if the little baby has a fever?"and "Can we hear her heart?".

The same medical appeal seems to happen in baby doll Analú Sorinho's package (Figure 9), ${ }^{12}$ whose box clearly reads: "Agora você pode brincar de médica de verdade" (Now you can play the doctor for real). 
Once again, the doll's attribute is set right in its name: Analú Sorinho (Little Serum), and here the future mother incorporated by the child needs to master certain skills prescribed in the box: "You should apply the little serum, the little injection, and change the diapers whenever the baby pees" (Você aplica o sorinho, injeçãozinha e troca a fraldinha quando bebê fizer xixi").

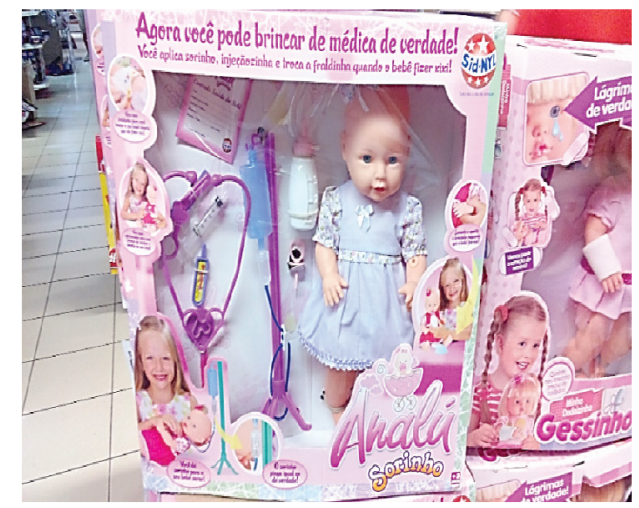

Figure 9: Multimodal features in the package of Brazilian baby doll Analú Sorinho ${ }^{13}$ [Photo:author]

Following the trend of Minha Dodoizinha Gessinho, baby doll Analú Sorinho's package expands the medical agenda by adding more sophisticated vocabulary items to the child's language as it brings, apart from the plastic stethoscope and a pair of plastic scissors, a baby bottle, a pacifier, a thermometer, a box of diapers, cotton wool, a syringe, serum, and a serum support together with the doll. A baby health card control is also included in the list, as if reminding the child that s/he needs to keep control of the baby's welfare from early age.

In fact, instructions are given both at the verbal and the visual level by means of six realistically depicted photographs of a young blonde little girl aged around six years old, placed around the package, displaying - and explaining - through structured and unstructured analytical images ${ }^{14}$ (see Unsworth, 2001, p. 86) how the child should take care of her baby: "Você dá o sorinho para o bebê sarar"(You should give serum for the baby to heal); "Vem com a fraldinha para você trocar o seu bebê depois dele fazer xixi" (It comes with a little diaper for you to change your baby after it pees); "Vem com estetoscópio para você brincar de escutar o coração do seu bebề" (It comes with a stethoscope so you can play listening to your baby's heart); "O sorinho pinga igual ao de verdade" (The serum drips like the real one).

Neither Minha Dodoizinha Gessinho nor baby doll Analú Sorinho make sounds that emulate real baby ones, but their naturalistic modality level increases through other systems that call for their representational function: they get as close to "the real thing" as they can cry real tears, their heart beats like a real one and they get sick like real babies do and therefore they need their mothers to care for them.

On the other hand, at the sensory level, the degree of representation in dolls like Nina Baby ${ }^{15}$ and Betsy Doll is revealed whenever these dolls are exposed to sunlight: their cheeks turn red. Such multimodal property not only emulates the red cheeks of a real person when exposed to the sun, but it also 
attaches an anthropomorphistic feature to these dolls' transforming features, by making them become more humanised or rather "made to look like children in a process of pedomorphism" (Brougère, 2014, p. 249), assigning the dolls with a children-like form.

In multimodal terms, both their naturalistic and sensory modality are maximised at a high level (Figure 10):
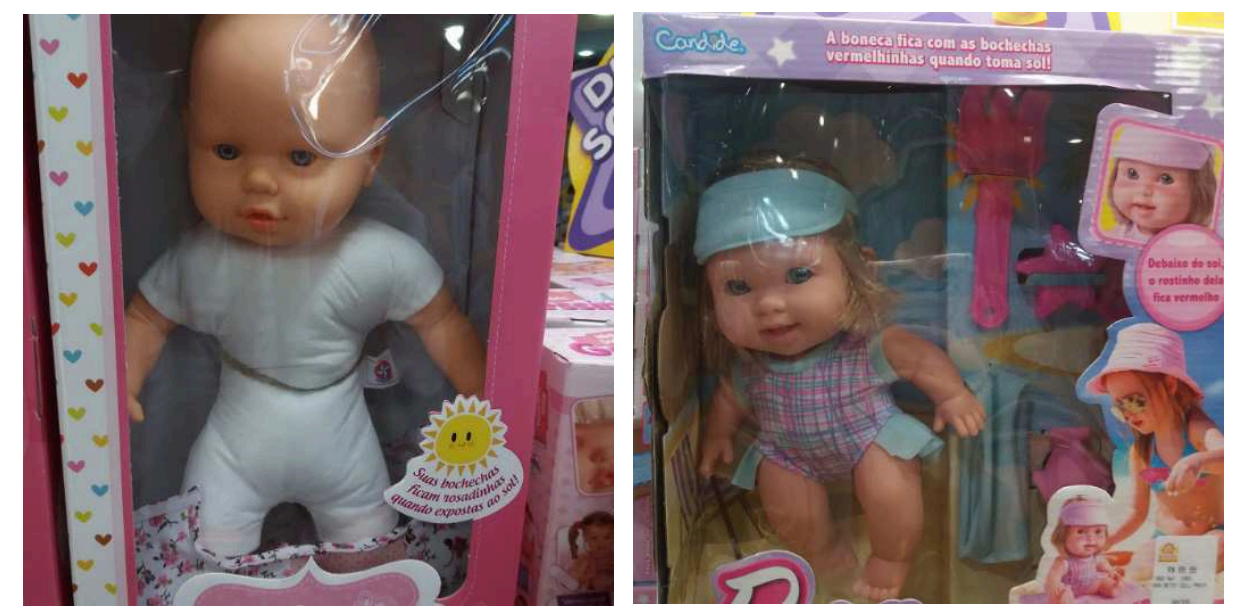

Figure 10: Multimodal features in the package of Brazilian baby dolls Nina and Betsy Doll [Photos:author]

In these dolls' boxes, their texts reinforce that their cheeks turn red when they get exposed to sunlight rays: "Suas bochechas ficam rosadinhas quando expostas ao sol"1" (Nina Baby); "A boneca fica com as bochechas vermelhinhas quando toma sol ${ }^{17}$ " and "Debaixo do sol o rostinho dela fica vermelho ${ }^{18}$ ".

At the instructional level, the visual text of Betsy Doll further elucidates to the child through an illustration of a young girl in bathing suit that it is essential not to forget to wear a protection hat, as this doll's designers seem to have opted for attaching an educational aspect to its discourse.

All in all, what the multimodality contained in the discourses of these five Brazilian baby dolls under analysis has demonstrated is that producers seem to be increasingly narrowing down children's meaning-making potentials by telling them both at the verbal and the visual level, how to play and what to expect in terms of the playing affordances reinforced by these dolls' material properties.

Through an increasingly high degree of representation in the baby dolls I am found available in the toy market, we are led to believe that their messages are clear insofar as gender roles are concerned.

\section{Final Considerations}

This article has attempted to look at the multimodal properties - including the aural, verbal and visual aspects of the representations of 5 (five) Brazilian baby dolls - anchored on Kress \& van Leeuwen's (2006) subsystem of modality (reality value), within the interpersonal visual metafunction of their Grammar of Visual Design. 
What the analyses of the baby dolls' packages under investigation seem to have revealed is that some of the tendencies in past dolls' representations still remain in contemporary times: traditional roles varying from parenting duties to medical abilities young girls are supposed to master in order to care and nurture for their "children". These are just some of the various cumulative tasks female children are expected to know from very early age in order to accomplish a society's expectations of them as future mothers.

A clear illustration of this is that contemporary baby dolls usually come with a list of "prescriptions" in their packages, telling the female child what her motherly duties will be while playing with this type of dolls. That includes feeding the baby, putting him/her to sleep, taking him/her to the doctor, changing his/her diapers and applying injections: "you should give serum for the baby to heal"; "you should apply the little serum, the little injection, and change the diapers whenever the baby pees", say the accompanying verbal texts on the baby dolls' packages under analysis.

Just as it happens in real life, as a result, these baby dolls will cry, speak, pee and make all sorts of sounds that emulate a newborn, instantiated by the toy industry's high modality devices.

Having said that, it is possible to argue that despite the verified transition in contemporary media representations towards the depiction of little girls playing more active roles as princesses in Disney movies, the traditional roles are still there, guiding them to design their childhood according to society's preestablished expectations, with the child-mother having to nurture and care for her little baby, even though she is still a baby herself.

Going back to the questions that generated this analysis, concerning the roles that little girls are expected to assume and how they relate to women's position in contemporary society, it can be therefore said that although new narratives have been added in the toy agenda over the past years, it is still the traditional that rules the roost in relation to baby dolls: the packages keep on predominantly picturing Caucasian little girls whilst black babies occupy the back shelves in mainstream toy stores and no boys have been seen sharing with the girls pictured on the boxes the hardworking task of raising a child.

\section{Acknowledgments}

This article is part of a project entitled Multimododality and Childhood | Multimodalidade e Infância, sponsored by the National Council for Scientific and Technological Development (CNPq), within the category Scholarship of Research Productivity.

I would like to thank toy store RiHappy and The Strong National Museum of Play, in Rochester, New York, USA, for understanding the scientific nature of my research and allowing me to use the pictures that illustrate this article. 
Notes

1. Since this article is part of a larger project aimed at revisiting the findings of a previous study on toys' discourse, it may contain some unpublished excerpts extracted from the author's $\mathrm{PhD}$ thesis.

2. Baby doll Coleção Nino’s (Figure 7) is manufactured by Cotiplás, a Brazilian-based toy company.

3. "It smells and weighs like a real baby". Translated from its original language, Portuguese. My translation.

4. All images included in this article belong to the author's personal archive, taken during a visit to toy store RiHappy on Brazilian Children's Day celebrated on $12^{\text {th }}$ October 2016.

5. "Press here and hear the sounds of a baby". Translated from its original language, Portuguese. My translation.

6. My Little Sick Plaster Doll. Translated from its original language, Portuguese. My translation.

7. Baby doll Minha Dodoizinha Gessinho (Figure 8) is manufactured by Sid Nyl, a Brazilian-based toy company.

8. All images included in this article belong to the author's personal archive, taken during a visit to toy store on Brazilian Children's Day, 12 ${ }^{\text {th }}$ October 2016.

9. "You may take off and put on my little plaster". Translated from its original language, Portuguese. My translation.

10. “Can we hear her heart?” Translated from its original language, Portuguese. My translation.

11. "I've broken my arm, I need someone to care for me". Translated from its original language, Portuguese. My translation.

12. Baby doll Analú Sorinho (Figure 9) is manufactured by Sid Nyl, a Brazilian-based toy company.

13. All images included in this article belong to the author's personal archive, taken during a visit to a toy store on Brazilian Children's Day, 12 ${ }^{\text {th }}$ October 2016.

14. Analytical structures portray participants in terms of a 'part-whole' relation wherein 'the whole' stands for 'the carrier' and 'the parts' for its 'possessive attributes' (ibid.). Analytical images may be classified as (1) structured, whenever they present labels which relate to their parts or (2) unstructured, when no labels are used to show part-whole relationships (Kress \& van Leeuwen, 2006).

15. Baby dolls Nina (Figure 10) and Betsy Doll are manufactured by Estrela and Candide, respectively, Brazilian-based toy companies.

16. "Her cheeks get red when exposed to the sun" (Nina Baby). Translated from its original language, Portuguese. My translation.

17. "The doll gets red cheeks when exposed to the sun" (Betsy Doll). Translated from its original language, Portuguese. My translation.

18. "Under the sun her little face gets red" (Betsy Doll). Translated from its original language, Portuguese. My translation..

\section{References}

Almeida, D. B. L. (2006) Icons of Contemporary Childhood: A Visual and Lexicogrammatical Investigation of Toy Advertisements. PhD Dissertation. Florianópolis: Universidade Federal de Santa Catarina. 
Brougère, G. (2014) Toys or the Rhetoric of Children's Goods. In: Machin, D. (Ed.). Visual Communication. Series: Handbooks of Communication Science [HoCS] Vol. 4. Berlin: DeGruyter Mouton, p. 243-259.

Fleming, D. (1996) Powerplay: toys as popular culture. Manchester: Manchester University Press.

Jewitt, C.; Oyama, R. (2001) Visual Meaning: a Social Semiotic Approach. In: Handbook of Visual Analysis. London: Sage, p. 134-156.

Kline, S. (1993) Out of the Garden: Toys and Children's Culture in the Age of Marketing. London: Verso Press.

Knafo, D. (2017) The Age of Perversion: Desire and Technology in Psychoanalysis and Culture. USA: Routledge.

Kress, G. \& van Leeuwen, T. (2006). Reading images: The Grammar of Visual Design. London: Routledge.

Machin, D.; van Leeuwen, T. (2009). Toy as discourse: children's war toys and the war on terror. Critical Discourse Studies, 6 (1) 51 - 64. Routledge.

Peers, J. (2004) The Fashion Doll: from Bébé Jumeau to Barbie. Oxford: Berg.

Ravelli, L. ; Almeida, D. B. L. (2013) Interview with Louise Ravelli. Ilha do Desterro, v. 64 , p. $233-248$.

Unsworth, L. (2001) Describing Visual Literacies. In: Teaching Multiliteracies across the Curriculum - Changing contexts of texts and image in classroom practice. Philadelphia: Open University Press. pp. 71-112.

van Leeuwen, T. \& Caldas-Coulthard, C. (2000) Iconography of the Pram Rattle - A Research for the Toys as Communication Research Programme.

Varney, W. (1999) Toys, play and participation. In: Brian Martin (ed.), Technology and Public Participation. Wollongong, Australia: Science and Technology Studies, University of Wollogong, p. 15- 36.

(2002) Love in Toytown. M/C: A Journal of Media and Culture, 5,(6) Winnicott, D.W. (1971). Playing and Reality. London: Tavistock.

Recebido em: 29/06/2017

Aceito em: 20/04/2018 